\title{
Acid Black 194 Dye Clarifications Onto Natural And Acid/Base Activated Smectitic Clays
}

\author{
Salima Chakroun ( $\square$ rousa.I.tn.9225@gmail.com ) \\ University of Tunis El Manar: Universite de Tunis El Manar \\ Haitham Elleuch \\ Tunis El Manar University: Universite de Tunis El Manar \\ Dalel Sghaier \\ Tunis El Manar University: Universite de Tunis El Manar \\ Mohamed Gaied \\ Université de Sousse Institut Supérieur des Beaux-Arts de Sousse: Universite de Sousse Institut Superieur des Beaux-Arts de Sousse
}

\section{Research Article}

Keywords: Tunisian clays, Acid/base activation, Characterization, Clarification, Acid Black 194 dye

Posted Date: December 17th, 2021

DOI: https://doi.org/10.21203/rs.3.rs-1173338/v1

License: @ (1) This work is licensed under a Creative Commons Attribution 4.0 International License. Read Full License 


\section{Abstract}

The present work is concerned the Acid Black 194 dye adsorption by Two smectitic clays (BJ and AJ) aged upper Eocene were sampled from Atlas Central of Tunisia in Kairouan region. Technical characterization was carried out using calcimetry and X-ray diffraction. The activation studies of clays by $\mathrm{HCl} / \mathrm{Na}_{2} \mathrm{CO}_{3}$ have been conducted to improve their physicochemical properties. The optimum result of the surface area after acid activation (aa) was $398 \mathrm{~m}^{2} / \mathrm{g}$ for BJ aa and AJ aa, after basic activation (ab) the surface area was $460 \mathrm{~m}^{2} / \mathrm{g}$ for BJ ab and 440

$\mathrm{m}^{2} / \mathrm{g}$ for $\mathrm{AJ}$ ab. The characterization by XRD, chemical analysis and SEM observations, were performed before and after optimum activation.

Moreover, the raw and activated samples (aa/ab) under the optimum activation conditions were used in the effluent treatment. Adsorption tests were made by batch system at $25^{\circ} \mathrm{C}$ in different $\mathrm{pH}(2-12)$ and by varying the adsorbent amount (0.025-0.1 g). The best adsorption results were recorded with $\mathrm{pH}=11$ and amount adsorbent $0.025 \mathrm{~g}$. The raw clay adsorption capacity was slightly better than activated samples. The best yield was given by BJ (94\%). Therefore, clay can be used in various applications without any characteristic modification.

\section{Introduction}

Organic synthetic dyes are compounds used in many industries such as automotive, chemical, stationery and more particularly the textile sector. These dyes are little or no biodegradable. In fact, they contain aromatic rings in their chemical structure that, in turn, hold delocalized electrons along with different functional groups. The auxochrome groups (as electron donors), are ionizable groups like $\mathrm{NH}_{2}, \mathrm{OH}, \mathrm{COOH}, \mathrm{SO}_{3} \mathrm{H}$ types etc [1-2]. It allows to ensure the solubility in the water, and especially to create more or less solid bonds between the dye and substrate responsible for dyeing capacity. Thus, the auxochromes groups define the tinctorial class. Actually, the presence of amine groups characterizes a basic dye and that of sulphonic groups characterizes the acid dyes (even in the presence of amino groups), while chromophore (as electron acceptors) imparts color to these dyes. Within the molecular structure, all chromophores have in common the presence of a series of conjugated double bonds, among which there exist most often aromatic or pseudo aromatic nuclei such that $-\mathrm{C}=\mathrm{C}-,-\mathrm{C}=\mathrm{O},-\mathrm{C}=\mathrm{N}-,-\mathrm{NO}_{2},-$ $\mathrm{N}=\mathrm{N}$ groups and quinonoid rings [1-3]. Hence, the dyes are classified on two bases, the first of which is the chromophoric groups in their chemical structures as azo, anthraquinone and phthalocyanine dyes, and the second one, it is the method of application as disperse dyes for polyester and reactive dyes for cotton [4]. Besides, the dyes can be acid, basic, or dispersed nonionic dye [5]. Among these categories, azo aromatic is the most extensively used element in the worldwide industry [6].

The affinity between the textile and the dyes varies according to the dye chemical structure and the fibers type to which they are applied (textile fibers, paper, leather, plastics...) [7]. These dyes are evacuated with liquid effluents that are mostly directly discharged to watercourses without prior treatment. It is estimated that about $7.10^{5}$ tons/year of dyes are produced in the world [8-9]. These colored discharges represent problems to the human health because many dyes are toxic similarly to hazardous organic compounds [10-11]. The textile industry discharges concentrated in dyes harm the environment, and affects ground and surface water resources as well as soil properties. Following this great environmental threat, the discoloration of textile rejects has been the subject of numerous studies. Therefore, the need to be treated or removed before their disposal or dispersal into water stream or surrounding environment has become imperative [12].

Several treatment methods have been developed, such as coagulation-flocculation, precipitation, ion exchange, irradiation and ozonation, oxidation and membrane filtration [13]. However, these processes are expensive and lead to the generation of large sludge amounts or to the derivatives formation [14]. Recently, the best method for organic dye removal is the adsorption [15]. The adsorption capacity hinges upon the adsorbent, adsorbate variety and the solution condition [16]. Although the activated carbon is a frequently used in water treatment, it is seen as very costly and difficult to preserve. That is why, several research works are oriented to the use of natural materials [17], whose abundance in the earth crust (covering about $42 \%$ of the earth's crust) [18] justifies this interest. Previous studies have shown the potential of natural or treated clays to decontaminate these dyeing effluents due to their wide properties [19].

In Tunisia, many deposits of calcium bentonite are recognized as Eocene and the Upper Cretaceous outcrops. Eocene calcium bentonite deposits are extensively dispersed in Central Tunisia [20-21]. In this perspective, the use of Eocene smectitic clay, in Central Tunisia, as an adsorbent is of great interest thanks to its efficiency, accessible cost and abundance.

The aim of this work is to characterize representative samples collected from the Central Tunisian sites to be used as an adsorbent for the textile dye removal. To do so, many parameters of activation and their effect on the environment were studied.

\section{Samples And Techniques}

\section{1. Sampling and geological setting}


Two raw clays used were collected from Kairouan region in the Central Atlas of Tunisia (Fig. 1). Clay BJ is sampled from the upper limb of the

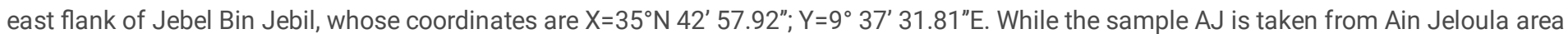
whose coordinates are $\mathrm{X}=35^{\circ} \mathrm{N} 51^{\prime} 15.19^{\prime \prime} ; \mathrm{Y}=9^{\circ} 49^{\prime} 35.09^{\prime \prime} \mathrm{E}$. The clay samples were kept in an oven at $60^{\circ} \mathrm{C}$, and then crushed to be later tested by calcimetry and mineralogical analysis.

\section{2. Clay activation}

The raw clays ( $\mathrm{BJ}$ and $\mathrm{AJ}$ ) used were activated by $\mathrm{HCl}(\mathrm{aa})$ or by $\mathrm{Na}_{2} \mathrm{CO}_{3}(\mathrm{ab})$. Activation test series were performed by testing concentration acid $(0.1,0.3,0.5,0.7$, and $1 \mathrm{~N})$ or base $(2,3,5$ and $10 \%)$, activation times $(1,2,4$ and $6 \mathrm{~h})$ and activation temperatures $\left(25,50,75\right.$ and $\left.90^{\circ} \mathrm{C}\right)$ [22]. For preparing acid-activated clay (aa), the treatment consists in shaking a clay with a solution of HCl of known concentration of a ratio of $1 \mathrm{~g} / 30 \mathrm{ml}$ [23-21]. Thus, the suspension was filtered and washed numerous times with distilled water until pH 5 . While clays activated by the base were used without washing. Lastly, the treated materials were dried in an oven at $105^{\circ} \mathrm{C}$ for $24 \mathrm{~h}$. The raw and activated clays under optimal conditions, having the greatest surface area were used in the effluent clarification tests.

\section{3. Instrumental and Technical analyses}

The percentage of $\mathrm{CaCO}_{3}$ was determined from raw samples (BJ and $\mathrm{AJ}$ ) by using a Bernard calcimeter. The mineralogical identification was carried out by $\mathrm{X}$-ray diffractometer with copper Ka radiation, and the generator parameters $(40 \mathrm{~mA}, 45 \mathrm{kV})$ and step size in [ $2 \mathrm{Th}$.] was of the order of $0.0170^{\circ} \mathrm{s}$ for all samples (raw, aa and $\mathrm{ab}$ ). The used apparatus was of the Philips X 'Pert type. Not only were oriented aggregates treated with ethylene glycol, but also dried in an oven at $500^{\circ} \mathrm{C}$ for $2.5 \mathrm{~h}$. The surface area was determined by methylene blue (spot test method) [24]. The chemical composition of clay (raw, aa and ab) was determined by ICP-AES. The loss on ignition (LOI) was determined by means of gravimetric method of analysis and measured at 105 and $1000^{\circ} \mathrm{C}$ for $1 \mathrm{~h}$. It corresponds to the weight percent of the difference between the calcined samples. The determination of the clay morphology was conducted by Analytical Scanning Electron Microscope (SEM), model JSM-5400. Furthermore, the absorbance of the treated effluent was measured by UV-visible spectrometer (Perkin Elmer, Lambda 25).

\section{4. Adsorbate}

The effluent to be treated emanating from leather tannery rejects is loaded with a synthetic organic dye called Acid Black 194 dye, whose chemical formula is $\mathrm{C}_{20} \mathrm{H}_{12} \mathrm{~N}_{3} \mathrm{NaO}_{7} \mathrm{~S}$ and molecular weight is $461.38 \mathrm{~mol} / \mathrm{g}$. It was kept refrigerated at $4^{\circ} \mathrm{C}$ and warmed to room temperature the following day before being tested.

\section{5. Batch adsorption process}

Adsorption tests were made by batch system using a water bath to control the temperature at $25^{\circ} \mathrm{C}$. Two adsorption parameters were varied such that $\mathrm{pH}$ was in the range of $2-12$ [25], and the adsorbent amounts were $0.025 ; 0.05$ and $0.1 \mathrm{~g}$. The effluent pH was adjusted by $\mathrm{HCl} /$ $\mathrm{NaOH} 0.5 \mathrm{M}$. The known amount of adsorbents (raw, aa or ab) was placed in erlenmeyer flask containing $50 \mathrm{ml}$ of effluent at known pH. The resulting mixture was then mixed continually for $15 \mathrm{~min}$ [26-21]. The solid-liquid suspension was filtered by polypropylene filters (0.45 $\mu \mathrm{m})$ and dye remaining in the supernatant was measured by spectrometer at $380 \mathrm{~nm}$ corresponding to the maximum absorbance $(\lambda$ max).

The percentage of adsorption capacity was calculated as follows Eq. (A1) [27]:

$\%$ adsorption capacity $=\frac{\left(c_{i}-c_{s}\right)}{c_{i}} \times 100$ Eq. (A1)

with:

$\mathrm{C}_{\mathrm{i}}$ : the initial concentration dye in the effluent $(\mathrm{mg} / \mathrm{l})$;

$\mathrm{C}_{\mathrm{e}}$ : the concentration dye in the effluent $(\mathrm{mg} / \mathrm{l})$ at contact time $\mathrm{t}$;

The amount of dye adsorbed per unit mass can be calculated using the following equation Eq. (A2) [28]:

$\mathrm{q}_{\mathrm{e}}=\left[\left(\mathrm{C}_{0}-\mathrm{C}_{\mathrm{e}}\right)\right] \mathrm{V} / \mathrm{m}$ Eq. $(\mathrm{A} 2)$

where,

$\mathrm{q}_{\mathrm{e}}$ : is the quantity of dye adsorbed on the adsorbent $(\mathrm{mg} / \mathrm{g})$;

$\mathrm{C}_{0}$ and $\mathrm{C}_{\mathrm{e}}$ : are the liquid phase concentrations of dye at initial and equilibrium, respectively (mg/l); 
$\mathrm{m}$ : is the quantity of clay used (g);

$\mathrm{V}$ : is the volume of dye solution (ml);

\section{Results And Discussion}

\section{1. Clays sample characterization}

The calcimetry results of the studied samples in Table 1 show that BJ clay has a slightly lower content (7\%) than AJ clay (10\%). As for the XRay diffraction analysis given in Table 1, it indicates that the samples clay are composed of smectite (85-99\%) associated with kaolinite (1$14 \%)$. Illite is only presented in the BJ sample with a low proportion of $1 \%$. The percentages of the associated no clay minerals are quartz (5$8 \%)$, calcite (6-12\%) and dolomite (7-10\%). The last two values confirm the calcimetry results. Gypsum, feldspar, as well as jarosite are present only within the sample (BJ) with contents of the order (5\%); (5\%) and (1\%), respectively.

The chemical analysis is shown in the Table 2, revealing that $\mathrm{SiO}_{2}$ and $\mathrm{Al}_{2} \mathrm{O}_{3}$ are the major constituents of the $\mathrm{BJ}$ and $\mathrm{AJ}$ clays. This hyperaluminous and hyper-siliceous nature offers the possibility to attribute these two elements to the clay phase [29]. In addition, the $\mathrm{CaO}$ level is higher in the AJ (8.51\%) sample than BJ (4.17\%), thus confirming the presence of carbonates. Therefore, the relatively high percentage of MgO (3-3.79\%) indicates the presence of dolomite, which is confirmed by the $\mathrm{DRX}$ analysis. Besides, these elements $\left(\mathrm{SiO}_{2}\right.$ and $\left.\mathrm{Al}_{2} \mathrm{O}_{3}, \mathrm{CaO}, \mathrm{MgO}\right)$ represent other oxides $\left(\mathrm{Na}_{2} \mathrm{O}\right.$ and $\left.\mathrm{K}_{2} \mathrm{O}\right)$ present in lower amounts.

The loss of ignition (LOI) of $\mathrm{BJ}(19.78 \%)$ is superior to that of $\mathrm{AJ}(17.17 \%)$. It is mainly accredited to the loss of $\mathrm{H}_{2} \mathrm{O}$ from clay minerals, especially smectite and $\mathrm{CO}_{2}$ originating from the decomposition of calcite and dolomite.

\section{2. Variation of activation parameters}

\section{2. 1. Acid/ basic concentration $\left(\mathrm{HCl} / \mathrm{Na}_{2} \mathrm{CO}_{3}\right)$ effect on clay surface area}

Figs. $2 \mathrm{a}-2 \mathrm{~b}$ show the results of concentration $\left(\mathrm{HCl} / \mathrm{Na}_{2} \mathrm{CO}_{3}\right)$ on the surface area under operating conditions $1 \mathrm{~h}$ time activation and temperature $25^{\circ} \mathrm{C}$.

In Fig. 2a pertaining to acid activation revealed that the surface area increased after activation at $0.1 \mathrm{~N}$. The best surface area is given by BJ aa, increasing from 366 to $398 \mathrm{~m}^{2} / \mathrm{g}$. Exceeding the $0.1 \mathrm{~N}$ concentration, the surface area of BJ aa decreased to $314 \mathrm{~m}^{2} / \mathrm{g}$ and stabilized until $0.7 \mathrm{~N}$. The increase of concentration to $1 \mathrm{~N}$ decreased again the surface area $293 \mathrm{~m}^{2} / \mathrm{g}$. However, for AJ aa, the activation of clay at $0.1 \mathrm{~N}$ increased the surface area from 303 to $356 \mathrm{~m}^{2} / \mathrm{g}$. Beyond this applied concentration, the surface gradually decreased to $262 \mathrm{~m}^{2} / \mathrm{g}$ at $1 \mathrm{~N}$. This can be explained by the fact that the increase of $\mathrm{HCl}$ at concentration superior to $0.1 \mathrm{~N}$, destroys the structure of the sheets, and consequently decreases the surface area. According to a previous research work elaborated by Baghdadli et al. 2016 [30], the acidic activation (0.1-0.7 N) of a typical Algerian montmorillonite causes a progressive degradation of the octahedral clay layers, thus resulting in the smectite structure. While in the basic activation case, the biggest surface area $440 \mathrm{~m}^{2} / \mathrm{g}$ for BJ ab and $408 \mathrm{~m}^{2} / \mathrm{g}$ for AJ ab are reached using $5 \%$ and $3 \%$ of $\mathrm{Na}_{2} \mathrm{CO}_{3}$, respectively. For $\mathrm{BJ}$ ab starting at $5 \%$ of $\mathrm{Na}_{2} \mathrm{CO}_{3}$, the surface area remained constant, whereas for $\mathrm{AJ}$ ab beyond $3 \%$, the surface area gradually decreased up to $387 \mathrm{~m}^{2} / \mathrm{g}$ (Fig. 2b). That is why, in the case of acid activation, the temperature was set at $25^{\circ} \mathrm{C}$ and the concentration of $\mathrm{HCl}$ was kept at $0.1 \mathrm{~N}$. Similarly, in the case of basic activation with $\mathrm{Na}_{2} \mathrm{CO}_{3}$, the retained concentrations were $5 \%$ for $\mathrm{BJ}$ ab and $3 \%$ for AJ ab in order to study the other activation parameters. According to the experimental results of several authors Lakevičs et al. 2014 [31], expanding the concentration of sodium hydroxide from mass 5 to $15 \%$, leads to the drop of the surface area. Consequently, the surface area of the modified clay is smaller than that of the natural clay.

\section{2. 2. Activation time effect on clay surface area}

The results of variation activation time $(1,2,4$ and $6 \mathrm{~h})$ on the surface area of $\mathrm{BJ}$ aa and AJ aa are given in Fig.2c. It is noted that, for BJ aa, one hour of activation was sufficient to obtain a better surface area of the order $398 \mathrm{~m}^{2} / \mathrm{g}$. Beyond this applied time, the surface decreased to $366 \mathrm{~m}^{2} / \mathrm{g}$ and stabilized at that level. Hence, for AJ aa, 2 hours of activation was necessary to increase the surface to $387 \mathrm{~m}^{2} / \mathrm{g}$. Beyond this time, the surface decreased slightly to $378 \mathrm{~m}^{2} / \mathrm{g}$.

Fig. $2 \mathrm{~d}$ shows the variation activation time $(1,2,4$ and $6 \mathrm{~h})$ on the surface area of $B J$ ab and $A J$ ab. The results obtained in these tests reveal that the increase of activation time for 2 hours generated a parallel increase with the surface area. For BJ ab, the surface increased to 460 $\mathrm{m}^{2} / \mathrm{g}$ and stabilized, while for AJ ab the surface reached its maximum at $440 \mathrm{~m}^{2} / \mathrm{g}$ and then from 4 hours, the activation decreased (419 $\mathrm{m}^{2} / \mathrm{g}$ ) and stabilized at that time. For this reason, we retained $2 \mathrm{~h}$ activations for all samples activated with acid/ basic activation, except for 
$\mathrm{BJ}$ aa, we kept $1 \mathrm{~h}$ activation and reserved the optimal concentrations of $\mathrm{HCl}$ and $\mathrm{Na}_{2} \mathrm{CO}_{3}$ of each sample giving the best surfaces. Similar results were reported by clay material used as adsorbent [21].

\section{2. 3. Effect of activation temperature on clay surface area}

The results obtained from the various temperatures $\left(25-90^{\circ} \mathrm{C}\right)$ on surface area are shown in Figs. $2 \mathrm{e}-2 \mathrm{f}$. It is evident that the temperature significantly affects the structure of the clay during activation.

The acid activation of BJ aa demonstrated that a temperature of $25^{\circ} \mathrm{C}$ was sufficient to give an optimal surface area (398 $\mathrm{m}^{2} / \mathrm{g}$ ). The surface area $377 \mathrm{~m}^{2} / \mathrm{g}$ slightly decreased with the increase of the temperature to $50{ }^{\circ} \mathrm{C}$. Unlike $\mathrm{AJ}$ aa, the application of a temperature above $50{ }^{\circ} \mathrm{C}$ augmented the area to $398 \mathrm{~m}^{2} / \mathrm{g}$ (Fig. $2 \mathrm{e}$ ).

During the basic activation, optimal areas for all samples are given at $25^{\circ} \mathrm{C}$ : an optimal surface area $460 \mathrm{~m}^{2} / \mathrm{g}$ for BJ ab and $440 \mathrm{~m} / \mathrm{g}$ for $\mathrm{AJ}$ $\mathrm{ab}$ are recorded. The increase of the temperature above $25^{\circ} \mathrm{C}$ caused a gradual decrease in the surface area of $\mathrm{BJ}$ ab and $\mathrm{AJ}$ ab, which stabilized from $75^{\circ} \mathrm{C}$, thus giving a surface of about 450 and $419 \mathrm{~m}^{2} / \mathrm{g}$, respectively (Fig. 2f). Therefore, the most important variables affecting the properties of the acid activated smectites are acid concentration, nature of treatment $\left(\mathrm{HCl}\right.$ or $\left.\mathrm{Na}_{2} \mathrm{SO}_{3}\right)$ temperature, shaking time, and dry (acid/badic)/clay ratio [32].

The aforementioned results confirmed that all samples were retained in the raw and activated states by $\mathrm{HCl} / \mathrm{Na}{ }_{2} \mathrm{CO}_{3}$, under the best activation conditions, giving the most important surfaces for the continuation of the study: $\mathrm{BJ}$ aa $\left(0.1 \mathrm{~N}, 1 \mathrm{~h}, 25^{\circ} \mathrm{C}\right)$; $\mathrm{AJ}$ aa $\left(0.1 \mathrm{~N}, 2 \mathrm{~h}, 50{ }^{\circ} \mathrm{C}\right)$; $\mathrm{BJ}$ ab $(5 \%, 2$ $\left.\mathrm{h}, 25^{\circ} \mathrm{C}\right)$ and $\mathrm{AJ}$ ab $\left(3 \%, 2 \mathrm{~h}, 25^{\circ} \mathrm{C}\right)$.

\section{3. Activation effect on the clay material}

\section{3. 1. Chemical analysis}

The results of the chemical analysis of the samples $\mathrm{BJ}$ and $\mathrm{AJ}$ at the raw and activated states by $\mathrm{HCl}$ and $\mathrm{Na}_{2} \mathrm{CO}_{3}$ are given in Table 2 . The $\mathrm{PF}$ decreased more strongly after acid activation than after basic activation. In fact, for BJ and AJ, the percentage PF decreased from 19.78 to $17.26 ; 17.17$ to 15.94 , respectively, after acid activation and from 19.78 to $19.01 ; 17.17$ to 16.87 , respectively, after basic activation. This affirms that the decomposition carbonates, dolomites is more effective by acid than by basic activation [33], further confirmed by the decrease in the $\mathrm{CaO}$ and $\mathrm{SO}_{3}$ content.

The release of cations in the solution is variable from one element to another, and depending on the type of activation, acid or basic. According to the literature, $\mathrm{Al}^{3+}, \mathrm{Fe}^{3+}$ and $\mathrm{Mg}^{2+}$ elements are cations that belong to the tetrahedral and octahedral layers of clay [34]. Although their dissolution is difficult, it can be progressive. The results found in our study show that whatever the activation used (acid/base), $\mathrm{Mg}^{2+}$ is $\mathrm{more}$ easily released than $\mathrm{Al}^{3+}$ and $\mathrm{Fe}^{3+}$, which proves that it is easily released and replaced by $\mathrm{H}^{+}$during acid activation. Nonetheless, aluminum percentage increased during acid activation and decreased after basic activation. This can be explained by the fact that the dissolution of aluminum by the acid is difficult, whereas it is favored by the base. According to previous research works, it is reported that the solubility of Al in clay minerals is easier by basic activation than acid activation [35]. Iron dissolution is very difficult because it is undissolved for all samples.

The losses recorded for $\mathrm{Mg}$ >> Al ions in ascending order after the acid activation can be explained by the forces of the metal-oxygen bonds $\left(\mathrm{EMg}-\mathrm{O}=362.3 \mathrm{~kJ} \mathrm{~mol}^{-1}\right.$, lower than EAl-O $\left.=507.5 \mathrm{~kJ} \mathrm{~mol}^{-1}\right)$ [34-36].

The $\mathrm{SiO}_{2}$ rate increases for the two samples $\mathrm{BJ}$ aa and $\mathrm{AJ}$ aa during acid activation from 42.22 to $48.35 \%$; 47.16 to $55.37 \%$, respectively, more than during basic activation from 42.22 to $42.35 \%$; 47.16 to $48.15 \%$, respectively. Consequently, the activation for a long time which results in the formation of amorphous silica leads to the destruction of crystalline clay [18]. Similar behavior was noted in the ratio of $\mathrm{Si} /(\mathrm{Al}+\mathrm{Fe}+\mathrm{Mg})$ which augmented in activated bentonite. Hydrochloric acid caused an increase of the $\mathrm{SiO}_{2}$ content due to the remobilization of octahedral cations [37-38].

In addition, while the $\mathrm{Na}^{+}$rate decreased during acid activation, it increased during basic activation. This proves that during acid activation there was a cationic exchange between $\mathrm{Na}^{+}$and $\mathrm{H}^{+}$of the acid in the interfoliar space of the clay and Ca-smectite recrystalization to Nasmectite during basic activation. According to this process, the $\mathrm{Na}^{+}$can totally replace the $\mathrm{Ca}^{2+}$ as interlayer cations [39], which is also in agreement with the results reported by Mosbahi et al. 2017 [33]. Previous studies Nguetnkam et al. 2005; Zorica et al. 2011 [40-41] have shown that during the activation of smectite clays, there is a leaching of octahedral $\mathrm{Al}^{3+}$ and substitution of exchangeable cations $\left(\mathrm{Ca}^{2+}\right.$ and $\left.\mathrm{Na}^{+}\right)$by protons in interlayer clay. 
Likewise, the $\mathrm{K}_{2} \mathrm{O}$ rate did not decrease during activation. This shows that this ion is difficult to release and belongs to the clay structural pattern.

\section{3. 2. Mineralogical Analysis}

The Figs. 3a - 3b show the X-ray pattern of the BJ and AJ samples before and after acid/ basic treatment under the optimal activation conditions. The diffractogram indicates a difference in smectite behavior according to the nature of the activation. In fact, during acid activation, the smectite line (ray) passed from 14.16 to $15.06 \AA$ for BJ aa, showing a more surface area due to the created pores and new surfaces following the partial decomposition of carbonates and sulphates, thereby to release the cations $\mathrm{Mg}^{2+}, \mathrm{Na}^{+}$and $\mathrm{Ca}^{2+}$ which are replaced by the proton $\mathrm{H}^{+}$[42]. These results substantiate the chemical analysis (Table 2). Moreover, the examination of the BJ aa spectrum demonstrated the increase of lines intensity (by the distinction of the peaks) located at $10.03 \AA$ characteristics of illite, confirming the removal of impurities, such as carbonates and sulphates. For AJ aa, the smectite line remained almost stable because the line of AJ and AJ aa are of the order of 14.92 and $14.95 \AA$. During basic treatment, the 001 order reflexion of smectite has been moved from 14.16 to $13.20 \AA$ for $B J$ ab and from 14.92 to $13.34 \AA$ for AJ ab, thus showing the transfer of a calcium smectite to a sodium smectite following Ca ${ }^{2+}$ replacements by $\mathrm{Na}^{+}$having smaller atomic radius. This is well confirmed by the chemical previously found analyses. Indeed, the CaO percentage decreased from 4.17 to $4.05 \%$ in the case of BJ ab and from 8.51 to $7.67 \%$ in the case of AJ ab (Table 2). Hence, the soda-activation modified properties of Ca-bentonites [39], which was also observed by several authors such as Mosbahi et al. 2017 [33].

Moreover, the content of quartz increased proportionally with the clays treated by hydrochloric acid or sodium bicarbonate and is related to the amorphous silica gel formation. Similar tendencies were also noticed with clay samples from Tūja (Devonian), and Laža (Quaternary) deposits [31].

\section{3. 3. Scanning Electron microscopy observations}

The SEM images of the raw and activated clays are displayed in Fig. 4. The micrograph of raw clay (Fig. 4a, d) shows that after their acid activation, the superposition of clay flakes became less dense and more porous through the dissolution of carbonates (Fig. $4 \mathrm{~b}$, e). This increases the intergranular space and the porosity of clays as previously reported in other studies by Tayebee and Mazruy in 2018 [43]. The basic activation has an influence on the clay particles size (Fig.4c, f), which show angular and irregular edges, thus becoming in an agglomerates form. This is probably due to the modification of the structure of the clay following the replacement of $\mathrm{Ca}^{2+}$ by $\mathrm{Na}^{+}$.

\section{4. Anionic dye removal}

\section{4. 1. Chemical formula and maximum wavelength of Acid Black 194 dye determination}

The chemical formula of the Acid Black 194 dye is illustrated in the Fig. 5a. A UV spectrum of dye was recorded from 200 to $800 \mathrm{~nm}$ using Perkin Elmer Lambda 25 UV-Vis spectrophotometer. The maximum absorbance wavelength ( $\lambda$ max) of Acid Black 194 was found to be at 380 $\mathrm{nm}$, and its visible spectrum is given in Fig. $5 \mathrm{~b}$.

\section{4. 2. Effect of pH on dye adsorption}

The study of colorant adsorption on BJ, BJ aa and BJ ab was carried out by mixing $0.05 \mathrm{~g}$ of adsorbent with $50 \mathrm{ml}$ of effluent during $15 \mathrm{mn}$ on a wide range of $\mathrm{pH}$ 2-12. The obtained results are presented in Table 3 which indicates that the electrostatic charges magnitudes are controlled by the $\mathrm{pH}$ [44-45]. Actually, the variation of the optical density of the effluent treated with the three types of clays (raw, aa and ab) remains almost similar, especially at $\mathrm{pH} 11$, where the adsorption yield of the dye is optimal. It was clearly noted that for these raw and activated clays (aa; ab), the optical density was high at acidic $\mathrm{pH}$ compared with that found at basic $\mathrm{pH}$ (9 to 12). The lowest values of optical density are recorded at $\mathrm{pH}$ 11. This shows that the basic $\mathrm{pH}$ acts on the anionic dye Black 194 and promotes its adsorption on the clay. Other studies have demonstrated similar results when many types of materials and dyes were used. Therefore, increasing the $\mathrm{pH}$ to 11 increases the adsorption capacity of methylene blue, which is explicate by the nature of surface charge of adsorbent and its interaction with the adsorbate [46-47].

Fig. 6 a shows that at a low pH (2-3), the percentage of adsorption anionic dye reached about $65 \%$ for BJ, $64 \%$ for BJ aa and $63 \%$ for BJ ab. Between $\mathrm{pH} 3$ and 7, the adsorption percentage diminished gradually to $56 \%$ at $\mathrm{pH} 7$. Beyond $\mathrm{pH} 8$, the adsorption capacity increased progressively until $\mathrm{pH} 11$, where it reached its maximum of the order $92.45 \%$ for $\mathrm{BJ}, 92.13 \%$ for $\mathrm{BJ}$ aa and $91.92 \%$ for $\mathrm{BJ}$ ab.

This behavior can be explained as follows: at pH acid, the Black 194 dye contains two nitrogen atoms charged positively against a negatively charged group $-\mathrm{SO}_{3}$. Thus, the electrical charge balance of the molecule is thus globally positive. This charge allows the dye to bind to the negative sites of the clay to form a complex (dye-clay) [26-48] (Fig. 7a). When the acidity of the effluent becomes low at pH between 4 and 7 , the active functions of bonding $(\mathrm{OH}$ and $\mathrm{N})$ of the dye with the adsorbent remain partly non-active or uncharged. Therefore, no electrostatic 
interaction is formed between the dye and the clay only by the group $\mathrm{SO}_{3}{ }^{-}$, and consequently the adsorption rate decreases. At pH superior to 8 , the environment becomes basic, the $\mathrm{OH}$ groups totally or partially convert into the form ionic $\mathrm{O}^{-}$depending on the $\mathrm{pH}$ of the effluent and the pKa of $\mathrm{OH}$ groups of dye. These charges allow the dye to bind to the positive sites of the clay to form a complex (dye-clay) (Fig. 7b). Similar results are reported by many previous studies that showed the influence of the $\mathrm{pH}$ environment on the overall dye charge and the surface of the adsorbent to form a link between the dye-loaded groups and the adsorbent [26-49].

Given that the lowest optical densities of the treated effluent are obtained at basic $\mathrm{pH}$ and more precisely at $\mathrm{pH} 11$, we have determined in what follows the discoloration percentage of effluent treated by AJ, AJ aa and AJ ab in the range of pH 10 to 12 . These data are also in accordance with other research work, in which the maximum adsorption of dye was achieved at pH11 [50]. Nonetheless, the optimal adsorption of malachite green dye was accomplished at $\mathrm{pH} 9$ by using $0.05 \mathrm{~g}$ of bentonite during $10 \mathrm{mn}$ [26].

\section{4. 3. Clarification percentage of effluent treated with $A J, A J$ aa and $A J$ ab as a function of $p H(10-12)$}

From the obtained optical densities of the effluents treated by the three types of clay (AJ, AJ aa, AJ ab) listed in table 3 , the adsorption capacities of the dye by the studied clays are deduced (Fig. 6b). According to these histograms, the activation of the clay (AJ aa/AJ ab) did not give an improvement in the adsorption capacity of the dye. The best adsorptions are recorded by the raw clay that varies between 89.42 and $92.18 \%$ in accordance with the variation of the $\mathrm{pH}(10-12)$. The higher adsorption (92.18\%) is given at $\mathrm{pH} 11 \mathrm{by} \mathrm{AJ}$. Similar results obtained by former studies have shown optimal adsorption (91\%) that was achieved using the same amount of $0.05 \mathrm{~g}$ clay at $\mathrm{pH} 9$ [26].

\section{4. 4. Adsorbed amount determination of dye by $B J, B J$ aa, $B J$ ab, $A J, A J$ aa and $A J$ ab at pH 11}

According to the best adsorption yields of the dye given at $\mathrm{pH} \mathrm{11,} \mathrm{the} \mathrm{adsorbed} \mathrm{amount} \mathrm{of} \mathrm{the} \mathrm{dye} \mathrm{was} \mathrm{determined} \mathrm{by} \mathrm{the} \mathrm{two} \mathrm{samples} \mathrm{(BJ,}$ $\mathrm{AJ})$, raw and activated, using a quantity of clay $0.05 \mathrm{~g}$.

The investigation of the quantity of adsorbed dye per unit mass of clay at $\mathrm{pH} 11$ is presented in table 4 . It is noted for all the samples that $1 \mathrm{~g}$ of clay was able to retain between 165 and $166 \mathrm{mg}$ of dye. Raw BJ and AJ have a slightly higher adsorption capacity than those activated acid/ basic clay of about 1\%. Along with the experimental results of other research works on the adsorption of dye (methylene blue) onto activated carbon prepared from rattan sawdust, the observed adsorption capacity was $294.14 \mathrm{mg} / \mathrm{g}$ [51].

\section{4. 5. Effect of the amount of clay on dye adsorption}

The influence of the amount of BJ, BJ aa, BJ ab, AJ, AJ aa and AJ ab adsorbent $(0.025 ; 0.05$ and $0.1 \mathrm{~g} / 50 \mathrm{ml})$ on dye removal was detected at $25^{\circ} \mathrm{C}, \mathrm{pH} 11$ and contact time $(15 \mathrm{mn}$ ) (Fig. 8a). The results revealed that for the six types of clays, an amount of $0.025 \mathrm{~g}$ was sufficient to displace $91.83-94.29 \%$ of the dye, and the best result was given by BJ (94.29\%). Likewise, the effect of the amount of adsorbent of activated bentonite ( 1 to $15 \mathrm{mg}$ ) on the adsorption malachite green $(40 \mathrm{mg} / \mathrm{l})$ is studied by Taybee and Mazy in 2018 [43]. A quantity of $0.01 \mathrm{~g}$ of adsorbent has shown a maximum adsorption of about $99 \%$.

The increase of clay amount introduced from $0.05 \mathrm{~g}$ leads to a gradual decrease of the adsorption capacity of clays BJ, BJ aa, BJ ab. This decrease was about $4 \%$ for a quantity used $0.1 \mathrm{~g}$. The visual examination coupled with the discoloring power of clays (BJ, BJ aa, BJ ab) confirms the obtained results (Fig. 8b). In this case, the small decrease of the adsorption capacity can be explained as follows:

When the adsorbent amount in industrial waste is little, the anions of the dye can easily occupy the superficial clay sites. Yet, the over addition of adsorbent generates difficulties for site occupation due to the particle agglomerations [52-21].

Besides, for AJ, AJ aa and AJ ab clays, the increase in the introduced amount of clay has almost no effect on the adsorption capacity which remains approximately stable. This behavior can be due to the number of adsorption sites that increase with the increase of the quantity of adsorbent until the mass $0.025 \mathrm{~g}$ from which the number of sites becomes constant. Such a phenomenon accords well with those observed by other authors Gupta et al. 2005, Tsai et al. 2007, Bennani Karim et al. 2010 [53-48-52] who have shown that, starting from a quantity of 0.04 g of clay, the adsorption of the methylene blue dye becomes constant.

\section{Conclusion}

The X-Ray diffraction analysis indicated that the BJ and AJ samples clay of the Upper Eocene age, are composed of smectite (85-99\%) associated with kaolinite (1-14\%) and low rates of no-clay minerals: quartz (5-8\%), calcite (6-12\%) and dolomite (7-10\%).

The optimal activation conditions with base $\left(\mathrm{Na}_{2} \mathrm{CO}_{3}\right)$ at a concentration of $5 \%$ for $\mathrm{BJ}$ and $3 \%$ for $\mathrm{AJ}$ for $1 \mathrm{~h}$ at $25^{\circ} \mathrm{C}$ gave higher surfaces than those obtained by acid activation $\left(\mathrm{BJ}:[\mathrm{HCl}]=0.1 \mathrm{~N}, 1 \mathrm{~h}, 25^{\circ} \mathrm{C}\right.$ and $\mathrm{AJ}:[\mathrm{HCl}]=0.1 \mathrm{~N}, 2 \mathrm{~h}, 50^{\circ} \mathrm{C}$ ), whose values are 460 and $440 \mathrm{~m}^{2} / \mathrm{g}$, respectively. 
The structure of the clay differs according to the type of acid/ basic activation. In fact, during acid activation, there is a cationic exchange between the interfoliar cation of clay and the $\mathrm{H}^{+}$of the acid, whereas during the basic activation, there is a transfer of a calcium smectite to a sodium smectite after $\mathrm{Ca}^{2+}$ replacements by $\mathrm{Na}^{+}$.

It appears that the adsorption capacity of dye by the clay depends essentially on pH effluent and the amount of adsorbent used rather than on the surface area importance. Moreover, the application of an amount of clay greater than $0.025 \mathrm{~g}$ in the treatment of the effluent loaded with Black 194 dye does not improve the adsorption of the dye. Actually, the best adsorption yields of the dye are given by the raw clays, about $94 \%$ for $\mathrm{BJ}$ and $93 \%$ for $\mathrm{AJ}$ using a quantity of clay $0.025 \mathrm{~g}$ at $\mathrm{pH} 11$.

It is also worth to note that the dye adsorption percentage in the best conditions ( $\mathrm{pH}=11$; amount of clay $=0.025 \mathrm{~g})$ is comparable between the raw clays (BJ; $A J)$ and activated (BJ aa, BJ ab, AJ aa and $A J$ ab) with a variation not exceeding $1 \%$.

\section{Declarations}

\section{Acknowledgments}

This work was supported by the National Office of Mines (O.N.M), the Tanning Industry of the Star in Tunis, and the Tunisian Enterprise of Petroleum Activities (ETAP).

\section{References}

[1] CARMEN Z. \& DANIELA S. (2012). Textile organic dyes-characteristics, polluting effects and separation/elimination procedures from industrial effluents - a critical overview. In: Puzyn T (eds.) Organic pollutants ten years after the Stockholm convention-environmental and analytical update, In Tech Press, Crotia, pp. 55-86.

[2] HAR BHAJAN S. \& BHARATI, KA. (2014). History of natural dyes. In: Singh HB, Bharati KA (eds.) Handbook of Natural Dyes and Pigments, Woodhead Publishing India, pp. 4-8.

[3] GURSES A., AÇIKYILDIZ M., GÜNES K. \& GÜRSES MS. (2016). Dyes and pigments: their structure and properties (ed): Charma, Sanjay K, Spinger Briefs in Molecular Science, pp. 13-29.

[4] HELMY HM., SHAKOUR AA., KAMEL MM. \& RASHED, SS. (2015). Impacts of Air Pollution on Colour Fading and Physical Properties of Wool Yarns Dyed with Some Natural Dyes in Residential Site. Journal Textile Science \& Engineering, vol. 5, $n^{\circ} 6,221$ p.

[5] CAMPOS R., KANDELBAUER A., ROBRA K.H., ARTUR C.P, \& GUBITZ G.M. (2001). Indigo degradation with purified laccases from Trametes hirsute and Sclerotim rolfsii. Journal of Biotechnology, vol. 89, $n^{\circ}$ (2-3), pp. 131-139.

[6] ASIF TAHIR M., BHATTI H. N. \& IQBAL M. (2016). Solar red and brittle blue direct dyes adsorption onto eucalyptus angophoroides bark: Equilibrium, kinetics and thermodynamic studies. Journal of Environmental Chemical Engineering, vol. 4, n 2, pp. $2431-2439$.

[7] HOSSAIN K., QUAIK S., ISMAIL N., RAFATULLAH M., AVASAN M. \& SHAIK R. (2016). Bioremediation and Detoxification of the Textile Wastewater with Membrane Bioreactor Using the White-rot Fungus and Reuse of Wastewater. Iranian Journal of Biotechnology, vol. 3, $n^{\circ} 3$, pp. 154-162.

[8] YAGUB M.T., SEN T. K., AFROZE S. \& ANG H. M. (2014). Dye and its removal from aqueous solution by adsorption. Advances in Colloid Interface Science, vol. 209, pp. 172-184.

[9] SAKIN OMER O., HUSSEIN M.A., HUSSEIN BHM. \& MGAIDI A. (2017). Adsorption thermodynamics of cationic dyes (methylene blue and crystal violet) to a natural clay mineral from aqueous solution between 293.15 and $323.15 \mathrm{~K}$. Arabian Journal of Chemistry, vol. 11 , ${ }^{\circ}{ }^{\circ}$, pp. $615-623$

[10] VISHWAKARMA S. K., SINGH M. P., SRIVASTAVA A.K. \& PANDEY V. K. (2012). Azo dye (direct blue 14) decolourization by immobilized extracellular enzymes of pleurotus species. Cellular \& Molecular Biology, vol. 58, n 1, pp. 21-25.

[11] KANT R. (2012). Textile dyeing industry an environmental hazard. Natural Science, vol. 4, n 1, pp. 22-26.

[12] ABOU-GAMRA Z. M. (2014). Kinetic and Thermodynamic Study for Fenton-Like Oxidation of Amaranth Red Dye. Advances in Chemical Engineering and Science, vol. 4, $n^{\circ} 3$, pp. 285-291. 
[13] Sing P, Nadim A \& Ezzedeen SR (2012) Leadership styles and gender: An extension. Journal of Leadership studies, vol. 5, $n^{\circ} 4$, pp. 6-19.

[14] BES-PIA A., MENDOZA-ROCA J. A., ROIG-ALCOVER L., IBORRA-CLAR A. \& ALCAINA-MIRANDA M. I. (2004). Nanofiltration of biologically treated textile effluents using ozone as a pre-treatment. Desalination, vol. 167, pp. 387-392.

[15] BEREZ A., AYARI F., ABIDI N., SCHAFER G. \& TRABELSI- AYADI M. (2014). Adsorption-desorption processus of azo dye on natural bentonite: batch experiments and modeling. Clay Minerals, vol. 49, pp. 747-763.

[16] DANESHVAR N., SALARI D. \& KHATAEE A. R. (2003). Photocatalytic degradation of azo dye acid red 14 in water: investigation of the effect of optional parameters. Journal of Photochemistry and Phtobiology A: Chemistry, vol. 157, pp. 111-116.

[17] GOMEZ V., LARRECHI M. S. \& CALLAO M.P. (2007). Kinetic and adsorption study of acid dye removal using activated carbon. Chemosphere, vol. 69, $n^{\circ} 7, p p .1151-1158$.

[18] HATTAB A., BAGANE M. \& CHLENDI M. (2013). Characterization of Tataouine's Raw and Activated Clay Chemical Engineering of Process Technology, vol. 4, $n^{\circ} 4$, p. 155.

[19] BERGAYA F., THENG B. K. G. \& LAGALY G. (2006). Handbook of Clay Science. Elsevier, Developments of Clay Science, 1st edn. Volume 1, Amsterdam, p. 124.

[20] JAMOUSSI F., BOUKADI N., BEDIR M., KHARBACHI S., ZARGOUNI F., GALINDO L. \& PAQUET H. (2003). Répartition des minéraux argileux et contrôle tectonoeustatique dans les bassins de la marge Tunisienne, Clay mineralogical distribution and tecto-eustatic contol in the Tunisian margin basins. Comptes rendus Geoscience, vol. 335, pp. 175-183.

[21] CHAKROUN S., MECHTI W., HERCHI M., \& GAIED M.E. (2018). Characterization of Ain M'Dheker clay deposits for sunflower oil and acid black 194 dye clarification. Arabian Journal of Geosciences, vol. 11, n60, 1-14.

[22] ELOUSSAIEF M. \& BENZINA M. (2010). Efficiency of natural and acid-activated clays in the removal of Pb (II) from aqueous solutions. Journal of Hazardous Materials, vol. 178, $n^{\circ} 1-3, p p .753-757$.

[23] WOUMFO D., KAMGA R., FIGUERAS F. \& NJOPWOUA D. (2007). Acid activation and bleaching capacity of some Cameroonian smectite soil clays. Applied Clay Science, vol. 37, n²1-2, pp. 149-156.

[24] CHAKROUN S., HERCHI M., MECHTI W. \& GAIED E. M. (2017). Acid activation of upper Eocene Ca-bentonite for soybean oil clarification. Environmental Science and Pollution Research, vol. 24, $n^{\circ} 28, p p .22557-22569$.

[25] AGHDASINIA H. \& RAHBARI ASIABI H. (2018). Adsorption of a cationic dye (methylene blue) by Iranian natural clays from aqueous solutions: equilibrium, kinetic and thermodynamic study. Environmental Earth Sciences, vol. 77, $n^{\circ}$ 5, pp. $218-242$.

[26] TAHIR S. S. \& NASEEM R. (2006). Removal of cationic dye from aqueous solutions by adsorption onto bentonite clay. Chemosphere, vol. $63, n^{\circ} 11, p p .1842-1848$.

[27] CHIENG H. I., ZEHRA T., LIM, LINDA B. L., PRIYANTHA N. \& TENNAKOON D. T. B. (2014). Sorption characteristics of peat of Brunei Darussalam IV: equilibrium, thermodynamics and kinetics of adsorption of methylene blue and malachite green dyes from aqueous solution. Environmental Earth Sciences, vol. 72, $n^{\circ} 7, p p$. 2263-2277.

[28] ÖZBAY N., YARGIÇ A. Ş., YARBAY-ŞAHIN R.Z. \& ÖNAL E. (2013). Full factorial experimental design analysis of reactive dye removal by carbon adsorption. Journal of Chemistry, 2013, Article ID 234904, 1-13.

[29] BRINDLEY G. (1951). X ray Identification and Crystal Structures of Clay Minerals: Mineralogical Society, London, p 345.

[30] BAGHDADLI M.C., MEGHABAR R. \& BELBACHIR M. (2016). Acid-activation Algerian montmorillonite as Heterogeneous catalysts for cationic polymerisation of styrene. Asian Journal of Chemistry, vol. 28, $n^{\circ}$ 6, pp. 1197-1204.

[31] LAKEVIČS V., STEPANOVA V., Skuja L., Dušenkova I. \& Ruplis A. (2014). Influence of alkali and acidic treatment on sorption properties of Latvian illite clays. Key Engineering Materials, vol. 604, pp. 71-74.

[32] FRANCISCO R., DÍAZ V. \& SANTOS P. S. (2001). Studies on the acid activation of brazilian smectitic clays. Quim Nova, vol. $24, n^{\circ} 3$, pp. 345-353. 
[33] MOSBAHI M., TLILI A., KHLIFI M. \& JAMOUSSI F. (2017). Basic activation of lower Eocene clay from Meknassy-Mezzouna basin (centerwestern Tunisia), synthesis of zeolite and clarification of soybean oils. Applied Clay Science, vol. 138, pp. 1-11.

[34] SRASRA E. \& TRABELSI-AYEDI M. (2000). Textural properties of acid activated glauconite. Applied Clay Science, vol. 17, $n^{\circ}$ 1-2, pp. 71-84.

[35] HUSSIN F., AROUA M. K. \& WAN DAUD W. M. A. (2011). Textural characteristics, surface chemistry and activation of bleaching earth: a review. Chemical Engineering Journal, vol. 170, $n^{\circ} 1$, pp. 90-106.

[36] BOUGUERRA NEJI S., TRABELSI M. \& FRIKHA M. H. (2009). Esterification of Fatty Acids with Short-Chain Alcohols over Commercial Acid Clays in a Semi-Continuous Reactor. Energies, vol. 2, $n^{\circ} 4$, pp. 1107-1117.

[37] AMARI A., CHLENDI M., GANNOUNI A. \& BELLAGI A. (2010). Optimised Activation of Bentonite for Toluene Adsorption. Applied Clay Science, vol. $47, n^{\circ} 3-4, p p .457-461$.

[38] BENDOU S. \& AMRANI M. (2014) Effect of hydrochloric acid on the structural of sodic-bentonite clay. Journal of Minerals and Materials Characterization and Engineering, vol. 2, $n^{\circ} 5, \mathrm{pp}$. 404-413.

[39] BOUSSEN S., SGHAIER D., CHAABANI F., JAMOUSSI B., BEN MASSAOUD S. \& BENNOUR A. (2015). The rheological, mineralogical and chemical characteristic of the original and the $\mathrm{Na}_{2} \mathrm{CO}_{3}$-activated Tunisian swelling clay (Aleg Formation) and their utilization as drilling mud. Applied Clay Science, vol. 118, pp. 344-353.

[40] NGUETNKAM J. P., KAMGA R., VILLIERAS F., EKODECK G. E., RAZAFITIANAMAHARAVO A \& YVON J. (2005). Assessment of the smectite clays obtained by statistically designed experiments. Chemical Engineering Journal, vol. 137, $n^{\circ} 2, p p .436-442$.

[41] ZORICA P. T., SVETLANA B. A. , BILJANA M. B., VESNA A. P., ALEKSANDAR R. D. \& SVJETLANA B. C. (2011). Modification of Smectite Structure by Sulphuric Acid and Characteristics of the Modified Smectite. Journal of Agricultural Science, vol. 56, pp. 25-35.

[42] USMAN M. A., EKWUEME V. I., ALAJE T. O. \& MOHAMMED A. O. (2012). Characterization, acid activation, and bleaching performance of Ibeshe clay. Lagos, Nigeria, International Scholary Research Network ISRN Ceramics, pp. 1-5.

[43] TAYEBEE R. \& MAZRUY V. (2018). Acid-thermal Activated Nanobentonite as an Economic Industrial Adsorbent for Malachite Green from Aqueous Solutions. Optimization, Isotherm, and Thermodynamic Studies. Journal of Water Environmental and Nanotechnol, vol. $3, n^{\circ} 1, \mathrm{pp}$. 40-50.

[44] ONAL Y., AKMIL-BASAR C., EREN D., SARICI-OZDEMIR C. \& DEPCI T. (2006). Adsorption Kinetics of malachite green onto activated carbon prepared from Tuncbilek lignite. Journal of Hazardous Materials, vol. 128, no. 2-3, pp. 150-157.

[45] SHIRMADI M., MESDAGHINIA A., MAHVI A. H., NASSERI S. \& NABIZADEH R. (2012). Kinetics And Equilibrium Studies on Adsorption of Acid Red-18 (Azo-Dye)Using Multiwall Carbon Nanotubes (MWCNTs) from Aqueous Solution. E-Journal of Chemistry, vol. 9, $n^{\circ} 4$, pp. 23712383.

[46] AJBARY M., SANTOS A., MORALES-FLOREZ V. \& ESQUIVIAS L. (2013). Removal of basic yellow cationic dye by an aqueous dispersion of Moroccan stevensite. Applied Clay Science, $n^{\circ}$ 80-81, pp. 46-51.

[47] MEÇABIH Z., ROSE J. \& BORSCHNECK D. (2014). Urban Wastewater Treatment by Adsorption of organic Matters on Modified Bentonite by (Iron-Aluminium). Journal of Encapsulation and Adsorption Sciences, vol. 4, $n^{\circ}$ 3, pp. 71-79.

[48] TSAI W. T., HSU H. C., SU T. Y., YU LIN K., LIN C. M. \& DAI T. H. (2007). The adsorption of cationic dye from aqueous solution onto acidactivated andesite. Journal of Hazardous Materials, vol. 147, $n^{\circ} 3$, pp. 1056-1062.

[49] ADEYEMO A. A., ADEOYE I. O., BELLO O. S. (2017). Adsorption of dyes using different types of clays. Applied Water Science, vol. 7, $n^{\circ} 2$, pp. 543-568.

[50] FARAHANI M., SHEIKH ABDULLAH S. R., HOSSEINI S., SHOJAEIPOUR S. \& KASHISAZ M. (2011). Adsorption-based Cationic Dyes using the Carbon Active Surgarcance Bagasse. Procedia Environmental Sciences, vol. 10, pp. 203-208.

[51] HAMEED B. H., AHMAD A. L. \& LATIFF K. N. A. (2007). Adsorption of basic dye (methylene blue) onto activated carbon prepared from rattan sawdust. Dyes and Pigments, vol. $75, n^{\circ} 1, p p .143-149$. 
[52] BENNANI KARIM A., MOUNIR B., HACHKAR M., BAKASSE M. \& YAACOUBI A. (2010). Elimination du colorant basique « Bleu de méthylène » en solution aqueuse par l'argile de Safi. Revu des Sciences de l'eau, vol. 23, $n^{\circ}$ 4, pp. 375-388.

[53] GUPTA V. K., MITTAL A. \& GAJBE V. (2005). Adsorption and desorption studies of water soluble dye, Quinoline Yellow, using waste materials. Journal of Colloid and Interface Science, vol. 284, $n^{\circ} 1, p p$. 89-98.

\section{Tables}

Table 1 Calcimetry repartition and mineralogical composition of $\mathrm{BJ}$ and $\mathrm{AJ}$

\begin{tabular}{|c|c|c|c|c|c|c|c|c|c|c|c|}
\hline \multirow[t]{2}{*}{ Sample } & \multicolumn{7}{|c|}{$\%$ No clay minerals } & \multicolumn{3}{|c|}{$\%$ clay minerals } & \multirow{2}{*}{$\stackrel{\%}{\mathrm{CaCO}} 3$} \\
\hline & Quartz & Calcite & Gypsum & Dolomite & Feldspar & Jarosite & Pyhllosilicates & $\begin{array}{l}\text { Smectite } \\
\text { (Sm) }\end{array}$ & Kaolinite(K) & $\begin{array}{l}\text { Illite } \\
\text { (I) }\end{array}$ & \\
\hline BJ & 5 & 6 & 5 & 10 & 5 & 1 & 68 & 85 & 14 & 1 & 7 \\
\hline AJ & 8 & 12 & - & 7 & - & - & 73 & 99 & 1 & - & 10 \\
\hline
\end{tabular}

Table 2 Chemical composition of raw and activated clays samples

\begin{tabular}{|c|c|c|c|c|c|c|c|c|c|c|}
\hline \multirow[b]{2}{*}{ Sample } & \multicolumn{10}{|c|}{ Oxides \% } \\
\hline & $\mathrm{SiO}_{2}$ & $\mathrm{Al}_{2} \mathrm{O}_{3}$ & $\mathrm{CaO}$ & $\mathrm{MgO}$ & $\mathrm{Fe}_{2} \mathrm{O}_{3}$ & $\mathrm{Na}_{2} \mathrm{O}$ & $\mathrm{K}_{2} \mathrm{O}$ & $\mathrm{SO}_{3}$ & LOI & Total \\
\hline BJ & 42.22 & 17.14 & 4.17 & 3.79 & 6.53 & 0.22 & 1.20 & 2.31 & 19.78 & 97.36 \\
\hline BJ aa & 48.35 & 19.03 & 0.63 & 2.08 & 7.26 & 0.17 & 1.33 & 1.43 & 17.26 & 97.54 \\
\hline BJ ab & 42.36 & 16.37 & 4.05 & 3.71 & 6.54 & 2.43 & 1.16 & 2.52 & 19.01 & 98.19 \\
\hline AJ & 47.16 & 14.21 & 8.51 & 3.00 & 5.65 & 0.29 & 0.67 & 2.56 & 17.17 & 99.22 \\
\hline $\mathrm{AJ}$ aa & 55.35 & 14.59 & 1.88 & 2.48 & 6.52 & 0.08 & 0.73 & 1.30 & 15.94 & 98.87 \\
\hline$A J a b$ & 48.15 & 13.51 & 7.67 & 3.07 & 5.76 & 1.66 & 0.70 & 1.81 & 16.87 & 99.2 \\
\hline
\end{tabular}

Table 3 Optical density variations of BJ, BJ aa, BJ ab, AJ, AJ aa and AJ ab vs pH behaviour

\begin{tabular}{|c|c|c|c|c|c|c|c|c|c|c|c|c|}
\hline \multicolumn{2}{|c|}{ Sample } & \multirow{2}{*}{$\begin{array}{l}2 \\
2.26\end{array}$} & \multirow{2}{*}{$\begin{array}{l}3 \\
2.263\end{array}$} & \multirow{2}{*}{$\begin{array}{l}\mathbf{4} \\
2.34\end{array}$} & \multirow{2}{*}{$\begin{array}{l}5 \\
2.4\end{array}$} & \multirow{2}{*}{$\begin{array}{l}6 \\
2.782\end{array}$} & \multirow{2}{*}{$\begin{array}{l}7 \\
2.84\end{array}$} & \multirow{2}{*}{$\begin{array}{l}8 \\
1.75\end{array}$} & \multirow{2}{*}{$\begin{array}{l}9 \\
0.855\end{array}$} & \multirow{2}{*}{$\begin{array}{l}10 \\
0.733\end{array}$} & \multirow{2}{*}{$\begin{array}{l}11 \\
0.545\end{array}$} & \multirow{2}{*}{$\begin{array}{l}12 \\
0.625\end{array}$} \\
\hline$O D$ & BJ & & & & & & & & & & & \\
\hline & BJ aa & 2.35 & 2.386 & 2.386 & 2.65 & 2.79 & 2.86 & 2.25 & 1.236 & 0.792 & 0.566 & 0.671 \\
\hline & BJ ab & 2.4 & 2.715 & 2.715 & 2.793 & 2.88 & 2.89 & 2.35 & 1.7 & 0.892 & 0579 & 0822 \\
\hline & AJ & & & & & & & & & 0.738 & 0.562 & 0.636 \\
\hline & $\mathrm{AJ}$ aa & & & & & & & & & 1.015 & 0.59 & 0.661 \\
\hline & $A J a b$ & & & & & & & & & 1.48 & 0.607 & 0.683 \\
\hline
\end{tabular}

Table 4 Comparison of dye adsorption capacity by the clays studied

\begin{tabular}{|lllllll|}
\hline Samples & BJ & BJ aa & BJ ab & AJ & AJ aa & AJ ab \\
\hline Adsorbed amount (mg/g) & 166.42 & 165.84 & 165.46 & 165.94 & 165.15 & 164.68 \\
\hline
\end{tabular}

\section{Figures}




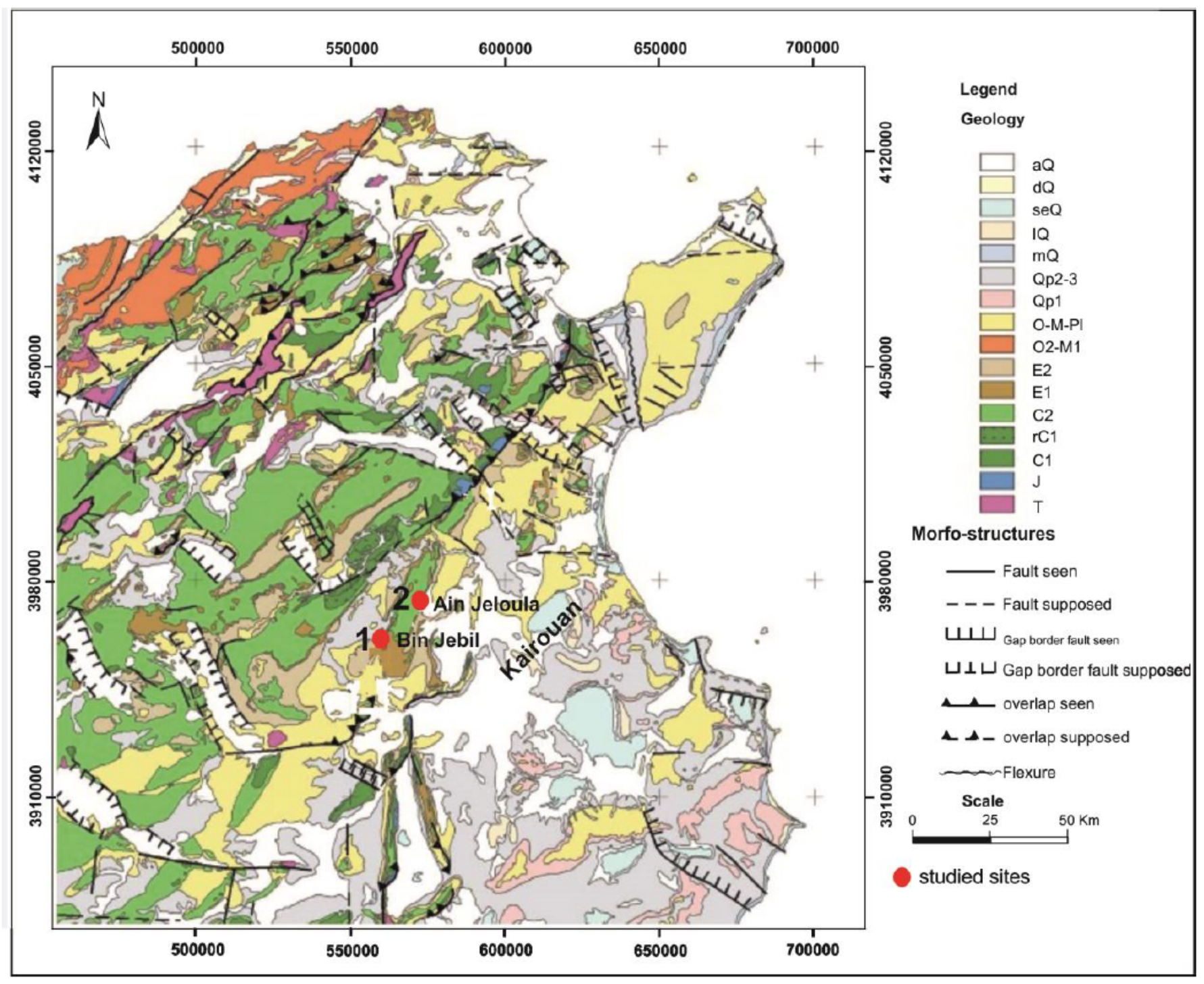

Figure 1

Geographical location of the studied sites 


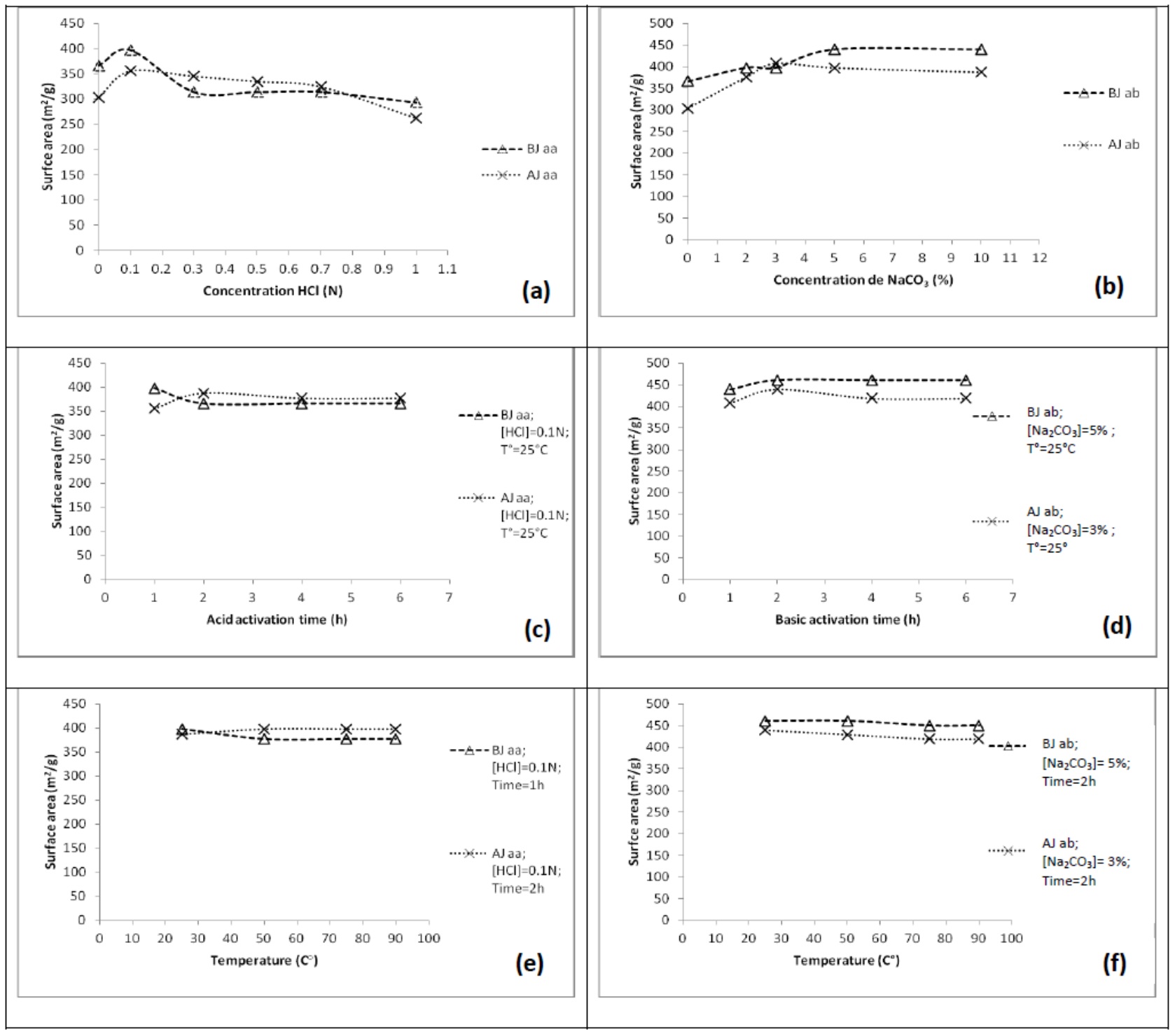

Figure 2

Variation of acid concentration ( $\mathrm{HCl})$ effect on surface area (a); Variation of basic concentration $\left(\mathrm{Na}_{2} \mathrm{CO}_{3}\right)$ effect on surface area (b); Activation time effect on surface area of clay treated with $\mathrm{HCl}(\mathrm{c})$; Activation time effect on surface area of clay treated with ( $\left.\mathrm{Na}_{2} \mathrm{CO}_{3}\right)(\mathrm{d})$; Temperature activation effect on surface area of clay treated with $\mathrm{HCl}(\mathrm{e})$; Temperature activation effect on surface area of clay treated with $\left(\mathrm{Na}_{2} \mathrm{CO}_{3}\right)(\mathrm{f})$ 


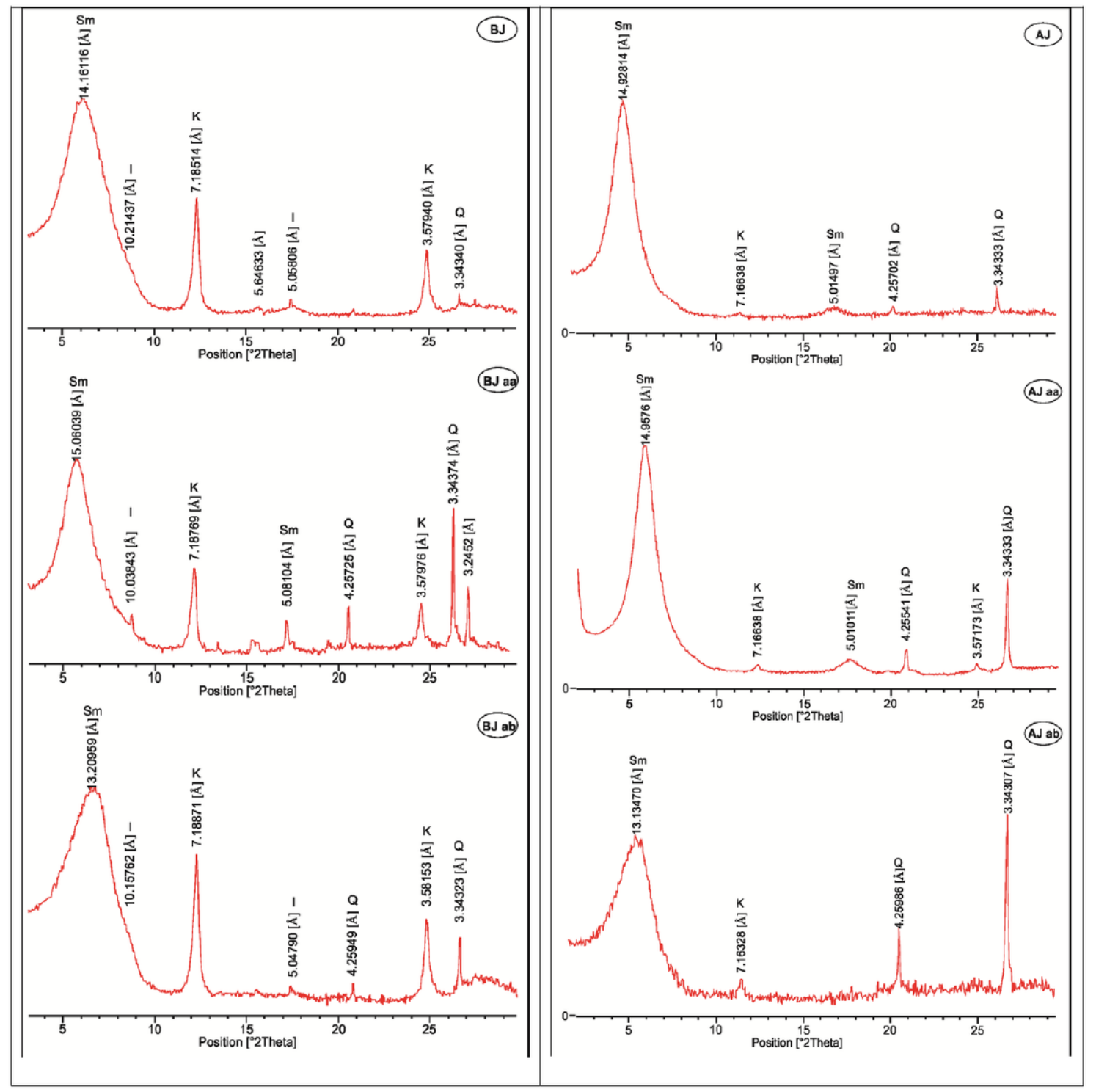

Figure 3

X-ray Diffractograms of raw (BJ) and activated clays BJ aa $\left(0.1 \mathrm{~N}, 1 \mathrm{~h}, 25^{\circ} \mathrm{C}\right) ; \mathrm{BJ}$ ab $\left(5 \%, 2 \mathrm{~h}, 25^{\circ} \mathrm{C}\right)(\mathrm{a})$; X-ray Diffractograms of raw (AJ) and activated clays $\mathrm{AJ}$ aa $\left(0.1 \mathrm{~N}, 2 \mathrm{~h}, 50^{\circ} \mathrm{C}\right) ; \mathrm{AJ}$ ab $\left(3 \%, 2 \mathrm{~h}, 25^{\circ} \mathrm{C}\right)(\mathrm{b})$ 

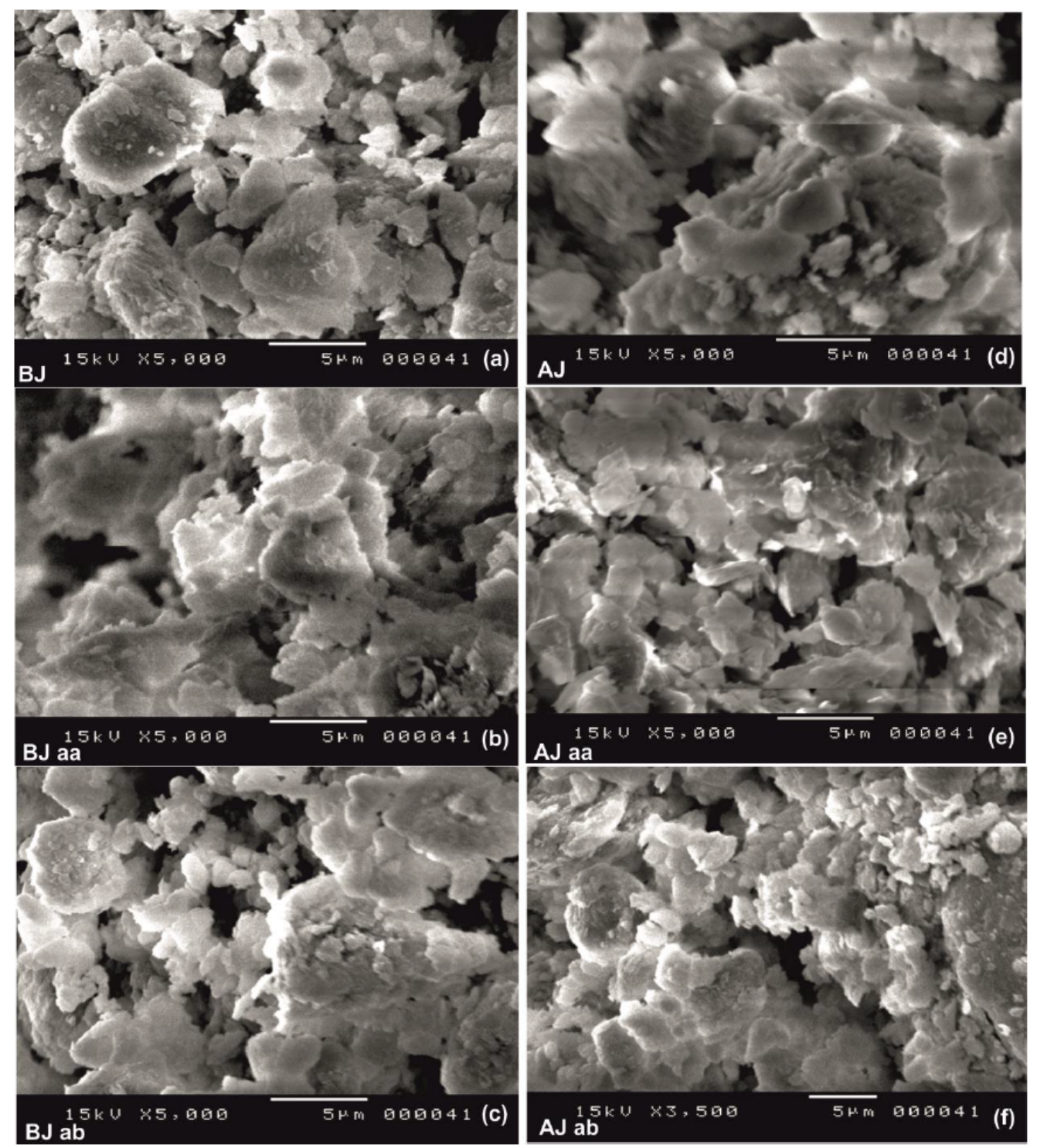

\section{Figure 4}

SEM of BJ and AJ samples (a, d); SEM of acid activated clays BJ aa $\left(0.1 \mathrm{~N}, 1 \mathrm{~h}, 25^{\circ} \mathrm{C}\right)$, AJ aa $\left(0.1 \mathrm{~N}, 2 \mathrm{~h}, 50^{\circ} \mathrm{C}\right)(\mathrm{b}, \mathrm{e})$; SEM of basic activated clays BJ ab $\left(5 \%, 2 \mathrm{~h}, 25^{\circ} \mathrm{C}\right)$, AJ ab $\left(3 \%, 2 \mathrm{~h}, 25^{\circ} \mathrm{C}\right)(\mathrm{c}, \mathrm{f})$

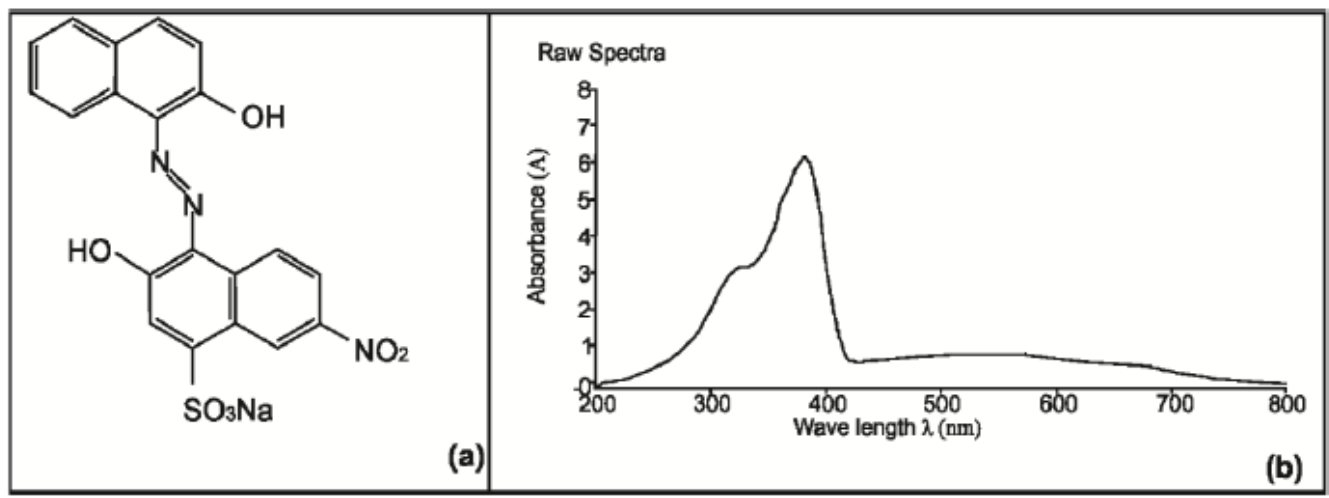

Figure 5 


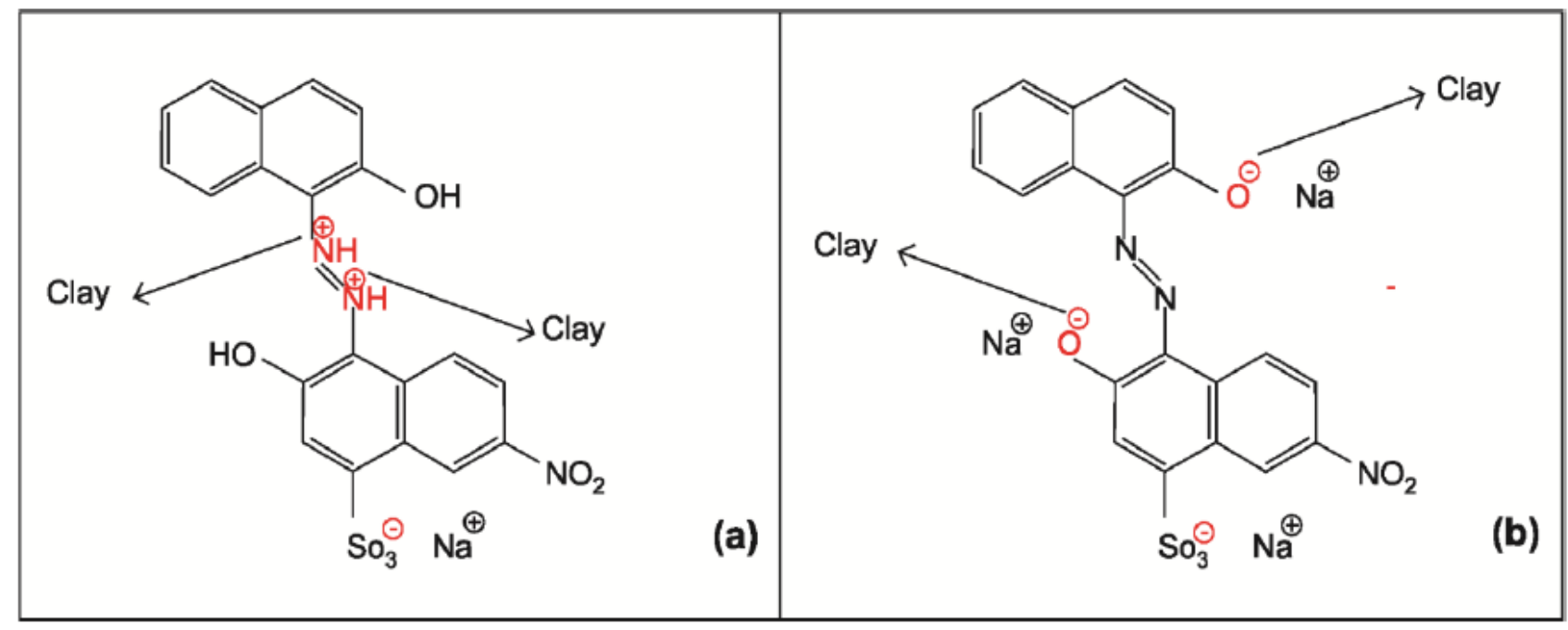

\section{Figure 6}

Effect of $\mathrm{pH}$ on adsorption of dye by BJ, BJ aa and BJ ab (a); Determination of percentage clarification of effluent treated with $\mathrm{AJ}, \mathrm{AJ}$ aa and AJ ab vs pH (10-12) (b) 


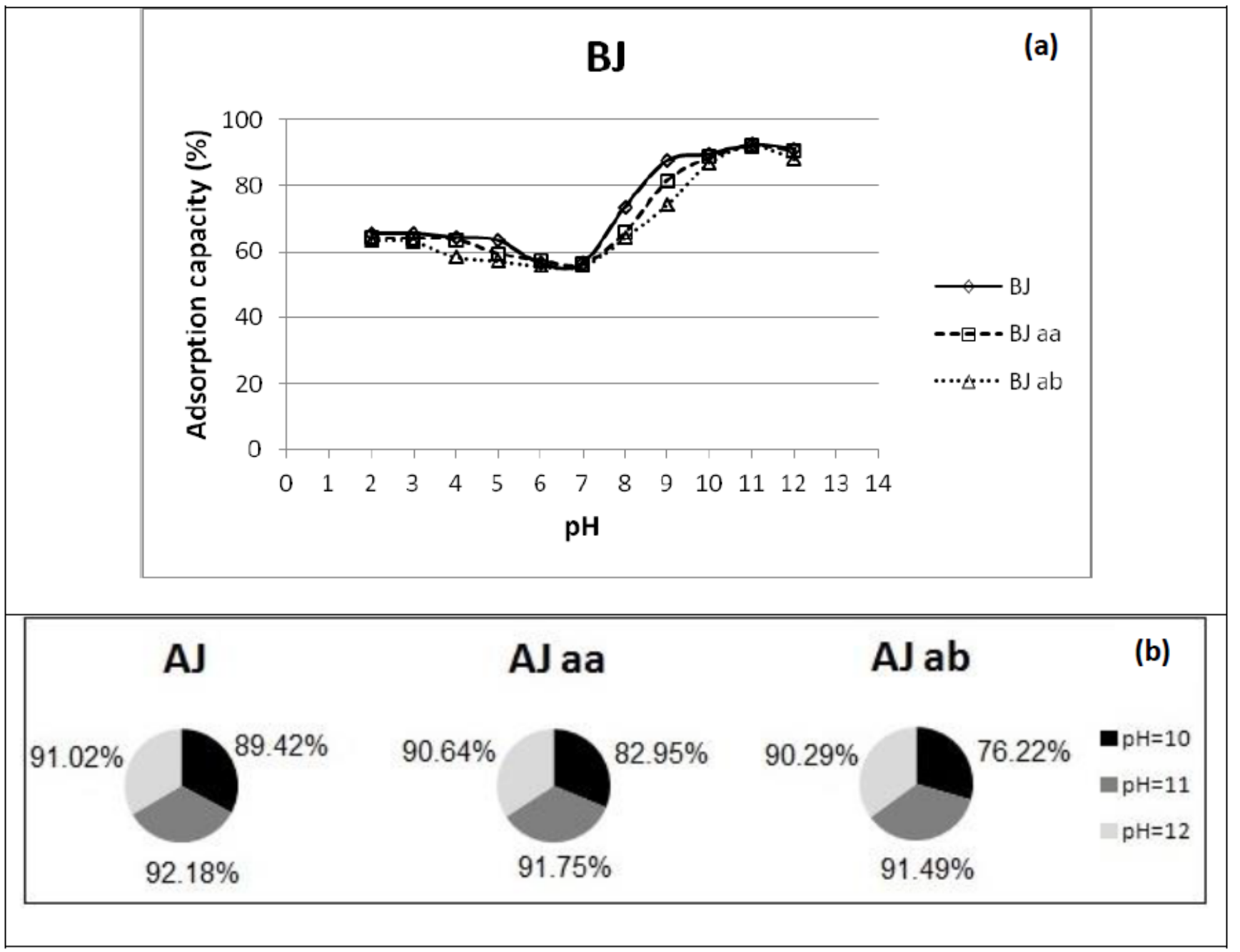

Figure 7

Clay fixation method with functional groups of Acid Black 194 dye in acid pH (a); Clay fixation method with functional groups of Acid Black 194 dye in basic $\mathrm{pH}(\mathrm{b})$; 


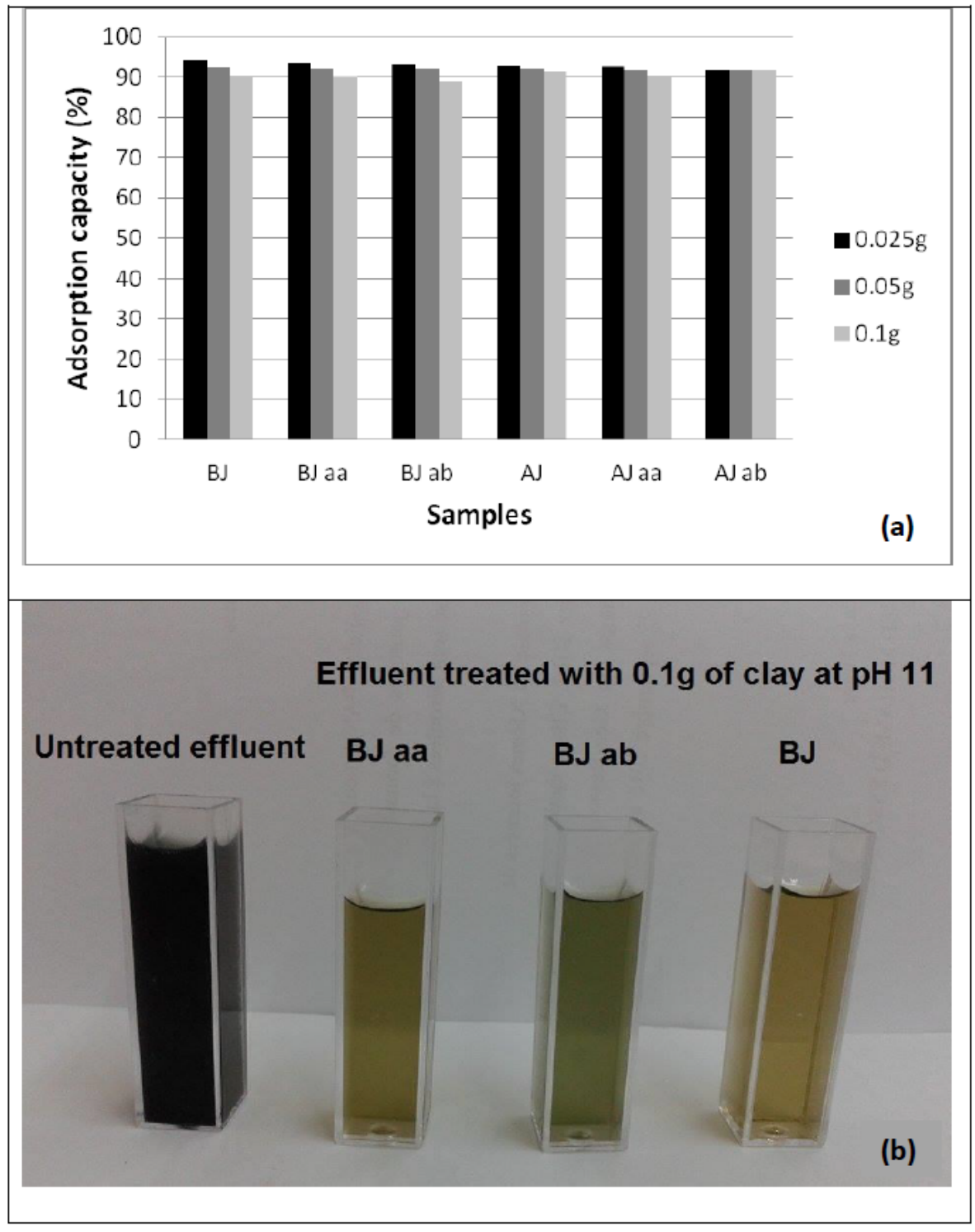

\section{Figure 8}

Effect of clay amount (BJ, BJ aa, BJ ab, AJ, AJ aa and AJ ab) on dye adsorption (a); Clarification of the effluent by BJ, BJ aa and BJ ab with amount $0.1 \mathrm{~g}$ at $\mathrm{pH} 11$ during $15 \mathrm{mn}(\mathrm{b})$ 